\title{
Cadre Empowerment and Exclusive Breastfeeding Assistance for Pregnant Women in Sempor Village, Sempor District, Kebumen
}

\author{
Kusumastutia), Dyah Puji Astuti, and Eti Sulastri \\ University Muhammadiyah Gombong, Gombong, Indonesia \\ a)Corresponding author: ncuz.kusuma26@gmail.com
}

\begin{abstract}
Breast milk is the ideal food for babies. Preparation for exclusive breastfeeding should start during pregnancy. The success of exclusive breastfeeding requires a lot of support from husband and family. Health volunteers are the spearhead of providing health information in the village so it is necessary to empower health volunteers in the socialization of exclusive breastfeeding to pregnant women. The purpose of the activity is to empower health volunteers regarding the importance of exclusive breastfeeding so that they can provide assistance on exclusive breastfeeding for pregnant women. The method of activity is to empower health volunteers about exclusive breastfeeding. Pre-test and post-test were carried out before the activity as an evaluation. The tools and materials used are LCD, screen, leaflet, questionnaire. A sample of 15 health volunteers. The results, before empowering health volunteers there were 8 health volunteers with sufficient knowledge of exclusive breastfeeding (53\%) and 2 health volunteers with good knowledge of exclusive breastfeeding (13.3\%). After empowering health volunteers, there was an increase in the knowledge of health volunteers, namely 13 health volunteers had good knowledge of exclusive breastfeeding (86.6\%) and the remaining 2 health volunteers had sufficient knowledge (13.3\%). At the mentoring stage, 15 health volunteers managed to provide assistance to 15 pregnant women who were willing to prepare themselves during pregnancy to provide exclusive breastfeeding to their babies after birth. The conclusion is that there is an increase in knowledge of health volunteers after empowering health volunteers so that pregnant women get assistance in preparing exclusive breastfeeding.
\end{abstract}

Keywords: Empowerment of health volunteers, exclusive breastfeeding

\section{INTRODUCTION}

Government Regulation No. 33 of 2012, Exclusive Breastfeeding (ASI) is breast milk that is given to babies from birth for six months, without adding and or replacing with food or other beverages (except drugs, vitamins, and minerals). Breast milk is the best food for babies that contains white blood cells, proteins, and immune substances that are suitable for babies. Breast milk helps children grow and develop optimally and protects against disease (Kemenkes RI, 2018).

One of the efforts to increase the quality of human resources is by giving breast milk (ASI) from an early age, especially exclusive breastfeeding. Babies need very high nutrients to maintain their lives. These needs can be fulfilled by giving breast milk (ASI) to babies. Breast milk is the ideal food for babies because breast milk contains all the nutrients to build and provide energy in the necessary order. Exclusive breastfeeding should be given in the first months after the birth of the baby, because at this time physical growth, psychomotor formation, and acculturation occur very quickly (Atabik, 2014).

The benefits of breastfeeding are so great, but there are still many mothers who do not want to give exclusive breastfeeding for six months for various reasons. The low coverage of the success of exclusive breastfeeding for infants, both in urban and rural areas, is influenced by many things. These include the lack of knowledge and lack of information to mothers and families about the importance of exclusive breastfeeding, hospital management or other birthing places which often do not apply bed-in (mother and baby are in one bed) or roomingin (mother and baby are in one room). or inpatient care), in addition to working mothers who find it difficult to breastfeed at work (Riksani, 2012). 
The incessant promotion and advertisement of bottled milk have influenced mothers to be interested in buying it, especially for mothers with low levels of knowledge and education. A mother's knowledge about the benefits of exclusive breastfeeding for babies is very important in determining the success of exclusive breastfeeding. In one study, the main obstacle to the success of exclusive breastfeeding was the lack of knowledge about breastfeeding and how to breastfeed correctly. Mother's knowledge about the advantages of breastfeeding and the correct way of breastfeeding will support the success of breastfeeding (Atabik, 2014).

Preparation for exclusive breastfeeding is ideally carried out during pregnancy. Increased knowledge of pregnant women about exclusive breastfeeding will motivate mothers to be able to give exclusive breastfeeding to their babies immediately after birth until the baby is 6 months old. Preparing for breastfeeding during pregnancy is important because, with better preparation, mothers are better prepared to breastfeed their babies. A mother's psychological preparation for breastfeeding during pregnancy is very meaningful because positive decisions or attitudes of mothers must occur during pregnancy or even long before as well as physical preparation in the form of breast examinations (Soetiningsih, 2012).

According to Sartono and Utaminingrum (2012), family support, especially husbands, can determine the success of exclusive breastfeeding because it can provide enthusiasm and a sense of comfort for mothers during breastfeeding which can affect increased milk production. The success of exclusive breastfeeding also requires a lot of support and participation from various parties, including health cadres because health cadres are people who often socialize with the community, including pregnant and lactating women. This cadre assistance to pregnant women is to provide support, motivation to pregnant women and their families to prepare for exclusive breastfeeding to their babies immediately after birth (Handayani \& Aprilina, 2017)

Percentage of exclusive breastfeeding for infants 0-6 months in Kebumen Regency for two years the last one tends to increase from 2017 as much as $50.7 \%$ and in 2018 as much as $66.95 \%$. This indicates the success of exclusive breastfeeding efforts. However, there is still a percentage of exclusive breastfeeding that is still below the standard, namely in the Sempor 1 Health Center area, which is $60.63 \%$ (Kebumen Health Office, 2018).

From the results of a field survey in Sempor Village which is the working area of the Sempor 1 Health Center, in December 2020 it was obtained data that there were 10 mothers of toddlers who had babies $0-6$ months. There are $50 \%$ of mothers under five who do not give exclusive breastfeeding for 6 months to their babies because the mother is already working, breast milk does not come out smoothly and there is a lack of support from the closest people. From the results of direct interviews with 5 health cadres at the village health post in Sempor, it was found that 2 people did not know about exclusive breastfeeding correctly. Based on this background, it is necessary to have a community service program through cadre empowerment and exclusive breastfeeding assistance for pregnant women in Sempor Village, Sempor District, Kebumen Regency.

\section{MATERIALS AND METHODS}

This community service activity method was carried out at the Sempor Village Hall on 01 February - 9 March 2021 with a total sample of 15 Health cadres. The tools and materials used in the activities include LCDs, screens, leaflets, pre-test, and post-test questionnaires. This community service activity includes the preparation, implementation, and evaluation stages. The preparation stage includes coordination with the village, village midwives, and cadres in determining the schedule of activities, as well as making media leaflets and questionnaires by the team. At the stage of implementing the activities by providing empowerment and health education/education to health cadres about exclusive breastfeeding directly/offline while always complying with the covid 19 prevention health protocol. Cadre assistance is carried out by identifying pregnant women whose house is located in the same RT with health cadres. At 
the activity evaluation stage, before and after the empowerment of cadres, carried out pre-test and post-test were to measure the level of knowledge of health cadres.

\section{RESULTS}

This community service activity is divided into several stages, namely the preparation, implementation, and evaluation stages. The activity preparation stage is carried out by coordinating with the Village Head, Village Midwife, and Sempor Village Health Cadres. Coordination activities were carried out on February 1, 2021, to determine the implementation of community service activities. In this preparatory activity, the service team held a meeting with a discussion on the technique of activities and the division of their respective tasks. The service team also carried out material preparation activities in the form of pre-test and posttest questionnaires, leaflets, and other supporting activities.

The second stage is implementation. At this implementation stage, 3 meetings were held with health cadres. The implementation was carried out at the Sempor Village Hall on 17 and 24 February 2021 and 03 March 2021. This activity was attended by the Village Head and the Sempor Village Midwife. Meeting I: Empowerment of Cadres by providing counseling to Health Cadres on Exclusive Breastfeeding by giving pre-test to 20 health cadres in Sempor Village. The materials provided include exclusive breastfeeding, preparation of exclusive breastfeeding during pregnancy for pregnant women, increasing milk production, and storing breast milk for working mothers. This activity was complemented by the presentation of leaflets and power points. The health cadres were very enthusiastic and followed the activity until it was finished.

Meeting II: Empowerment of Health Cadres by providing practices on how to prepare exclusive breastfeeding for pregnant women, increasing breast milk production and breast milk storage, and exclusive breastfeeding support. At this stage, an evaluation of the cadres was also carried out by distributing post-test questionnaires to the cadres at the end of the cadre empowerment session.

Meeting III: Assistance of pregnant women by Health cadres on the preparation of exclusive breastfeeding. A total of 15 health cadres assisted 15 pregnant women in preparation for exclusive breastfeeding. At this stage, cadres provide knowledge transfer about exclusive breastfeeding to pregnant women by providing counseling and assistance in preparing exclusive breastfeeding.

The third stage is evaluation. At the evaluation stage, the results obtained from measuring the knowledge of Health cadres before and after empowering cadres. Knowledge of cadres was obtained before empowering cadres, namely, there were 8 cadres with sufficient knowledge of exclusive breastfeeding (53\%) and 2 cadres with good knowledge of exclusive breastfeeding (13.3\%). After empowering cadres, there was an increase in cadre knowledge, as many as 13 cadres had good knowledge of exclusive breastfeeding (86.6\%) and the remaining 2 cadres had sufficient knowledge (13.3\%). In the mentoring stage, 15 cadres managed to assist 15 pregnant women in their area with pregnant women willing to prepare themselves to give exclusive breastfeeding to their babies after birth.

\section{DISCUSSION}

Exclusive breastfeeding is breastfeeding only for infants 0-6 months. Babies need very high nutrients to maintain their lives. Breast milk is the ideal food for babies because breast milk contains all the nutrients to build and provide energy in the necessary order. Exclusive breastfeeding should be given in the first months after the birth of the baby, because at this time physical growth, psychomotor formation, and acculturation occur very quickly (Atabik, 2014).

Preparation for exclusive breastfeeding is ideally carried out during pregnancy. Increased 
knowledge of pregnant women about exclusive breastfeeding will motivate mothers to be able to give exclusive breastfeeding to their babies immediately after birth until the baby is 6 months old. Preparing for breastfeeding during pregnancy is important because, with better preparation, mothers are better prepared to breastfeed their babies (Soetiningsih, 2012).

The success of exclusive breastfeeding also requires a lot of support and participation from various parties, including health cadres because health cadres are people who often socialize with the community, including pregnant and lactating women. This cadre assistance to pregnant women is to provide support, motivation to pregnant women and their families to prepare exclusive breastfeeding for their babies immediately after birth (Handayani \& Aprilina, 2017).

Cadres are community workers who are considered closest to the community. The role of cadres is very important in bridging the community, especially the posyandu target group. Various information from the government is more easily conveyed to the public through cadres. Because cadres are more responsive and have health knowledge above the average of the posyandu target group (Naim, 2008).

The public health cadres should have sufficient educational background to enable them to know about exclusive breastfeeding. Knowledge(knowledge)is the result out and this happens after people perform specific sensing of objects. Sensing certain objects through the five human senses, namely sight, hearing, smell, taste, and touch. Most of the human knowledge is obtained through the eyes and ears (Notoatmodjo, 2013). One of the empowerment methods is the lecture method which is a way of presenting lessons through oral narrative or direct explanations to a group of students (Notoatmodjo, 2011). The cadre empowerment method uses the extension method in providing health education about exclusive breastfeeding.

The factors that influence knowledge are age, interests, place of residence, sources of information, education, socio-culture, economy, and experience (Notoatmodjo, 2011). The results of the pre-test were obtained from the knowledge of cadres from before the empowerment of cadres, namely, there were 8 cadres with sufficient knowledge of exclusive breastfeeding (53\%) and 2 cadres with good knowledge of exclusive breastfeeding (13.3\%). After empowering cadres, there was an increase in cadre knowledge, as many as 13 cadres had good knowledge of exclusive breastfeeding (86.6\%) and the remaining 2 cadres had sufficient knowledge (13.3\%). There was an increase in the knowledge of cadres about exclusive breastfeeding after empowering health cadres. At the mentoring stage, 15 cadres were found to have successfully assisted 15 pregnant women in their area and pregnant women were willing to prepare themselves to provide exclusive breastfeeding to their babies immediately after birth until the age of 6 months.

\section{CONCLUSIONS AND RECOMMENDATIONS}

The conclusion from the community service that has been carried out is that there is an increase in cadre knowledge before and after cadre empowerment, namely 8 cadres with sufficient knowledge of exclusive breastfeeding (53\%) increased to 13 cadres having good exclusive breastfeeding knowledge (86.6\%). At the mentoring stage, 15 cadres managed to assist 15 pregnant women in their area with pregnant women willing to prepare themselves during pregnancy to provide exclusive breastfeeding to their babies after birth.

Suggestions for a follow-up plan need to be empowered by village midwives to empower cadres to improve the preparation of exclusive breastfeeding for pregnant women and increase exclusive breastfeeding for postpartum mothers starting in the class for pregnant women. 


\section{ACKNOWLEDGMENTS}

The Community Service Team would like to thank the University of Muhammadiyah Gombong LPPM, Sempor 1 Health Center, Sempor Village Head, and Sempor Village Midwives who have given permission, cooperation, and sponsorship in this activity so that this community service activity can run well.

\section{REFERENCES}

Ahmad Atabik. 2014. Faktor Ibu Yang Berhubungan Dengan Praktik Pemberian Asi Ekklusif Di Wilayah Kerjapuskesmas Pamotan. Unnes Journal of Public Health (UJPH 3 :1) http://journal.unnes.ac.id/sju/index.php/ujph

Dinas Kesehatan Kabupaten Kebumen. 2018. Profil Dinas Kesehatan Kabupaten Kebumen Fikawati S, Syafiq A, Karima K. 2015. Gizi Ibu dan Bayi. Jakarta: PT Raja Grafindo. Persada

Handayani, D.Y.\& Aprilina, H.A. 2017. Pemberdayaan Kader Posyandu Dalam Program ASI Eksklusif Di Desa Pemijen, Sokaraja, Banyumas. MEDISAINS,13(1)

Kemenkes RI. 2018. Menyusui sebagai Dasar Kehidupan dalam Infodatin Kemenkes Ri. Jakarta ISSN 2442-7659

Naim U. (2008). Posyandu Adalah Suatu Forum Komunikasi. Jakarta: Alih Teknologi Depkes RI.

Notoatmodjo, Soekidjo. (2011). Promosi Kesehatan dan Ilmu Perilaku. Jakarta: Rineka Cipta.

Notoatmodjo, Soekidjo. (2013). Pendidikan dan Perilaku Kesehatan. Jakarta: Rineka Cipta.

Riksani, R. 2012. Keajaiban ASI (Air Susu Ibu). Jakarta: Dunia Sehat.

Sartono, A., \& Utaminingrum, H. (2012). Hubungan Pengetahuan Ibu, Pendidikan Ibu dan Dukungan Suami dengan Praktek Pemberian Asi Eksklusif di Kelurahan Muktiharjo Kidul Kecamatan Telogosari Kota Semarang. Jurnal Gizi, 1(1).

Soetiningsih. (2012). ASI Petunjuk Untuk Tenaga Kesehatan. Jakarta: EGC 


\section{APPENDIX}

Table 1. Frequency distribution of Pre-test and Post-test cadre empowerment on exclusive breastfeeding

\begin{tabular}{ccccc}
\hline Variables & Pre Test & \multicolumn{3}{c}{ Post Test } \\
\cline { 2 - 5 } & Total & \% & Total & \% \\
\hline Good & 2 & 13.3 & 13 & 86.6 \\
Enough & 8 & 53.3 & 2 & 13.3 \\
Less & 5 & 33.3 & 0 & 0 \\
\hline Total & $\mathbf{1 5}$ & $\mathbf{1 0 0}$ & $\mathbf{1 5}$ & $\mathbf{1 0 0}$ \\
\hline
\end{tabular}

Table 1 shows the results of increasing knowledge of cadres before and after empowering cadres, 8 cadres with sufficient knowledge of exclusive breastfeeding (53\%) increased to 13 cadres who had good knowledge of exclusive breastfeeding (86.6\%). At the mentoring stage, 15 cadres managed to assist 15 pregnant women in their area with pregnant women willing to prepare themselves during pregnancy to provide exclusive breastfeeding to their babies after birth.

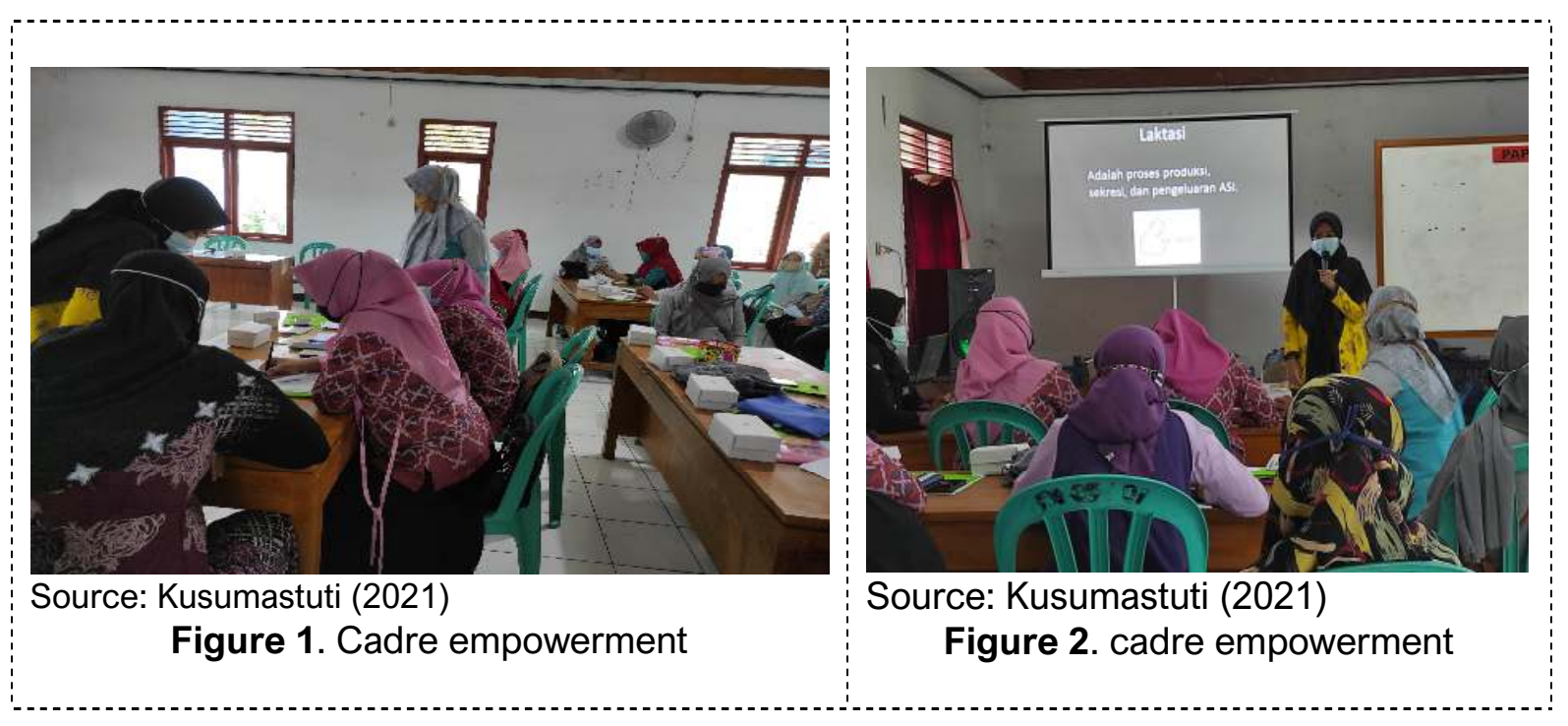

